\title{
Reflections on 50 Years of the Journal of the History of Biology
}

\author{
EVERETT MENDELSOHN \\ History of Science Department \\ Harvard University \\ Cambridge \\ USA \\ E-mail: emendels@fas.harvard.edu
}

On the desk in front of me, I have two copies of the JHB: Volume 1, Number 1, Spring 1968 and Volume 50, Number 3, Fall 2017. As I reflect on what led to the longevity and success of the journal, several things stand out. Scanning the tables of contents, it seems immediately clear, the authors of the published papers made for the strength of the JHB.

From the first paper by the young historian of ecology, Frank N. Egerton (then at the Hunt Botanical Library) on "Leeuwenhoek as a Founder of Animal Demography," through the succeeding 50 years, many of the authors were at early stages in their careers. This represented a conscious effort made by the editors to encourage young authors to submit papers which the editors and reviewers were committed to working on with the new scholars to bring the papers to publishable quality.

Several other editorial choices are evident. From the first volume to the most recent, international participation is apparent: M.D. Grmek (Paris) on Claude Bernard and V. Orel and M. Vavra (Prague) on Mendel's hybridization experiments to the most recent which includes Matthew Holmes (Leeds) on the Sparrow Question. In addition, practicing scientists, still at work in the laboratory or museum (Eg. R.C. Lewontin and Stephen Jay Gould in the first volume), contributed papers and reviews. Both Ernst Mayr and Conway Zirkle contributed papers in the second number of volume one.

Another feature introduced early in the JHB's publishing history was the organization of volumes focused on specific themes. Volume Two in enlarged form brought together philosophers of science (Dudley Shapere, Kenneth Schaffner, Morton Beckner, Michael Scrub and David 
Hull), active practicing biologists (Bentley Glass, Richard Lewontin, Clifford Grobstein, Joahn R. Platt, Ernest Nagel, Ernst Mayr), along with historians of biology (Garland E. Allen, Frederic L. Holmes, Frederick Churchill, Peter Vorzimmer) to examine questions of explanation in biology. Inclusion of studies in the philosophy of biology was a continuing theme in future years of the JHB.

Obviously the Journal could not have existed without attentive and inventive editorial guidance. Judith P. Swazey joined me as Assistant editor, as the journal got underway. Robert G. Frank, Jr. took on this role with Volume 5 and was joined by Diana Long Hall with Volume 6. Beginning with Volume 7, we added a staff editor, Nancy N. Clemente who took over much of the editorial preparations of accepted manuscripts for submission to the publisher. Her appointment coincided with a change in publishers from Harvard University Press to D. Reidel Publishing Company. Shirley Roe took over the roe of Associate Editor with Volume 14 and then took on more responsibility as Co-Editor. The Journal itself simultaneously was growing in size. Starting with Volume 15 (1982), three numbers were pub listed each year. This jumped to four numbers with the publication of Volume 39 (2006).

In the editorial preface of the first volume, we noted that the JHB "will attempt to serve as a forum both for the working biologist and the historian of the biological sciences." To fulfill this intention, active biologists who had evidenced an interest in the history of their scientific endeavors were recruited to the editorial boards of the Journal. Bentley Glass, Ernst Mayr and Jane Oppenheimer joined the initial editorial board; another group were members of the Advisory Editorial Committee: John Edsall, Ralph Gerard, Dickinson Richards, K.E. Rothschuh and Conway Zirkle. In honesty, we were also hoping to add gravitas to the journal by including names of widely respected scientists to our masthead. A number of these practitioners were also among early JHB authors. We included the Soviet geneticist, turned historian of genetics, A. E. Gaissinovitch on the Advisory Editorial Committee with Volume One. He went on to contribute a paper on the Late Nineteenth Century Russian heredity and variation in Volume 6 and another directly tackling the "Origins of Soviet Genetics and the Struggle with Lamarckism, 1922-1929," in Volume 13 (1980). His own career as an active geneticist had been cut short by the Soviet rejections of Mendelian genetics and he worked on the margins of Soviet society with a minor post in the History of Science unit of the Academy of Sciences. We had met at a meeting of the International Congress of the History of Science and Technology. 
No journal leaves an editorial office without a publisher. The JHB received a big push forward when the Harvard University Press chose to take on publishing. From the thoughtful cover design (which persists to this day) of David Ford to the careful management of Christopher Reed, the JHB had good friends at the HUP in its opening years. The Press was generous in its handling of the economic side of the newly established JHB in its formative years. With some wonder, I look back and note that the annual subscription rate was $\$ 7.50$.

In 1974, Harvard University Press decided to stop publishing periodicals and the JHB began a frantic search for a new publisher. We were lucky and after a few false starts, the Dutch publishers, D. Reidel Publishing Company (Dordrecht) took us on and we developed a quite friendly relationship with Anton Reidel, the son of the original founder and active director. Reidel itself merged with another Dutch publisher, Kluwer, in the 1990s and it in turn, merged with the German-based Springer Publishers in 2004. While the JHB continued to appear through all of these changes, the editors had to learn to quickly adjust to the business and editorial styles of each new publishing house.

Reflections on the establishment and continued success of the JHB must also include the seldom visible but absolutely essential role of the Department of the History of Science at Harvard and its generous and thoughtful staff. Space was made and secretarial assistance became the norm of the relationships of the JHB and the Department. Special appreciation of my secretarial assistant, Ruth Bartholomew, is warranted as she saw us through the critical and often uncertain early years of the JHB. 